\title{
EARLY KYIV OBSERVATIONS OF ASTEROIDS: ANALYSIS AND NEW REDUCTION WITH TYCHO-2 AND GAIA CATALOGS
}

\author{
S.V. Shatokhina ${ }^{1}$, L.V. Kazantseva ${ }^{2}$ \\ ${ }^{1}$ Main Astronomical Observatory of the National Academy of Sciences of Ukraine, Kyiv, \\ Ukraine,svetash@mao.kiev.ua \\ ${ }^{2}$ Astronomical Observatory of the Taras Shevchenko National University of Kyiv, Ukraine, \\ kazl@ukr.net
}

ABSTRACT. For more than 50 years, the continuous photographic observations of asteroids have been carried out with telescopes of the Astronomical Observatory of the Taras Shevchenko National University of Kyiv and the Main Astronomical Observatory of the National Academy of Sciences of Ukraine. About 3,000 photographic plates were obtained, some of which were exposed in 1908. We collected the data on more than 5,500 positions and magnitudes of asteroids on these astroplates taking into account all results of the processing of observations available in various publications and in the Minor Planet Center database.

All positional data were compared with JPL ephemeris and analyzed. From different series of asteroid observations the values of positional accuracy were obtained, depending on the methods of measuring and processing the plates and reference catalogs of stars.

In order to systematically improve the obtained asteroid positions, we evaluated the possibilities of reprocessing some of the earliest asteroid observations applying the modern star high accuracy catalogs.

Using the Tycho-2, Gaia DR2, and Gaia EDR3 as the reference catalogs, the 590 astroplates exposed on the MAO NASU Double Long-Focus Astrograph (DLA) in 1952-1986 were reprocessed based on old plate measurements. All newly determined and previous original asteroid positions were compared with the JPL ephemeris. The comparison results show an improvement in the systematic and random components of the accuracy of coordinates for new positions of asteroids. When comparing the new positions of the asteroids determined in the Tycho- 2 and Gaia catalog systems, no significant changes in accuracy were found.

Keywords: minor planets, asteroid positions, positional accuracy, reference star catalogs

АНОТАЦІЯ. Більш ніж 50 років безперервні фотографічні спостереження астероїдів проводились за допомогою телескопів Астрономічної обсерваторії Київського національного університету імені Тараса Шевченка та Головної астрономічної обсерваторії Національної академії наук України. Отримано близько 3 тисяч фотографічних платівок, окремі 3 яких були експоновані ще в 1908 р. На основі результатів обробки цих спостережень астероїдів, опублікованих у різних доступних нам виданнях та в базі даних Центру малих планет, були зібрані дані про положення та величини астероїдів. Всього накопичено понад 5500 положень і зоряних величин астероїдів.

Усі позиційні дані були порівняні 3 ефемеридами JPL та проаналізовані. За різними серіями спостережень астероїдів були отримані значення точності координат, різні в залежності від методів вимірювання і обробки платівок та опорних каталогів зірок.

Для покращення в систематичному відношенні наших положень астероїдів та, враховуючи високу точність та зоряну репрезентативність сучасних зоряних каталогів, ми оцінили можливості повторної обробки деяких із ранніх спостережень.

Використовуючи Тусhо-2, Gaia DR2 та Gaia EDR3 каталоги в якості опорних, 590 платівок, отриманих за допомогою подвійного довгофокусного астрографа MAO NASU у 1952-1986 роках, були пере-оброблені на основі старих вимірів платівок. Усі заново визначені та попередні оригінальні положення астероїдів були порівняні $з$ ефемеридами JPL. Результати порівняння вказують на покращення систематичної та випадкової складових точності координат для нових положень астероїдів у порівнянні з попередніми. При порівнянні нових положень астероїдів, визначених у системах каталогів Tycho-2 та Gaia, значних відмінностей в точності не виявлено.

Ключові слова: малі планети, положення астероїдів, точність координат, опорні каталоги зірок

\section{Introduction}

More than 50 years at the 20th century, the continuous photographic observations of asteroids have been carried out with telescopes of the Astronomical Observatory of the Taras Shevchenko National University of Kyiv (AO TSNU) and the Main Astronomical Observatory of the National Academy of Sciences of Ukraine (MAO NASU). About 3,000 photographic plates were obtained (Golovnia et al., 2017), the first of which were exhibited in 1908 and 1924-1925 by astronomers at the AO TSNU (Blažko, 1928; Putilin, 1929). To date, these unique observations have been digitized and identified, but have not yet been 
processed. The digitized data are stored in the Joint Digital Archive of the Ukrainian Virtual Observatory (UkrVO, http://gua.db.ukr-vo.org) (Vavilova et al., 2011; 2012; 2017; Vavilova, 2016).

The most successful observations of asteroids were processed and their positional data has been storing in the MPC database (https://minorplanetcenter.net//db_search). However, some of the data, both for early and later observations, was not included in the MPC archive, but was preserved only in publications. We have collected the most complete data on the positions of asteroids from these sources. The total number of asteroid positions determined from photographic observations at the $\mathrm{AO}$ TSNU and MAO NASU amounted to 5500 positions, the data on which were used for further analysis.

\section{Main results}

The observational period of asteroids is shown in Fig.1. The period 1946-1953 is the most representative for the early observations of asteroids in AO TSNU. Unfortunately, photographic plates from this period were not preserved in the archives of AO TSNU, but in previous times the plates were completely processed, and the results were published. Over the entire period of observations of asteroids on the Merz-Repsold astrograph (AMP, 200/4260) in 1933-1986, about 1000 positions of asteroids were determined (Vsekhsvyatskiy et al., 1950; Sandakova et al., 1950; Polupan et al., 1953; Konopl'ova et al., 1954; 1956).

At the MAO NASU, based on photographic observations, about 4500 positions of asteroids were determined. These are the early positions of selected minor planets, mostly bright $\left(5^{\mathrm{m}}-12^{\mathrm{m}}\right)$, the observations of which were initiated by the founders of the ORBITA observational program. They were carried out with two telescopes: the Long Focus Astrograph (DLA, 400/5500) in 1952-1986 and Wide Angle Astrograph (DWA, 400/2000) in 19761996 (Gavrilov et al., 1955; Gavrilov, 1957; 1958; Kolchinsky, 1956; Onegina, 1957; 1958; 1960; 1961; 1962; Demenko et al., 1958; Onegina et al., 1964; 1970; Vasilenko et al., 1979; Major et al., 1984; Kaltygina et al., 1985; Golovnya et al., 2001). The latest 2292 asteroid positions were obtained from digitized photographic observations of the Northern Sky Survey project in 19811995 (Andruk et al., 2016; Shatokhina et al., 2018). In most cases, these are fainter (up to the $16^{\mathrm{m}}$ ) asteroids, the images of which were recorded within the area of each plate. Detailed quantitative data of these observations are presented in Fig. 2.

To assess the accuracy of asteroid positions, we compared our positions with the JPL ephemeris (https:// ssd.jpl.nasa.gov/horizons). The resulting O-C differences were different for various periods of asteroid observations. The earliest observations were less accurate than the later ones.

In addition, we note that coordinates in the MPC database for the period 1930-1950 are given for some asteroid positions with an accuracy of 0.5 arc minutes.

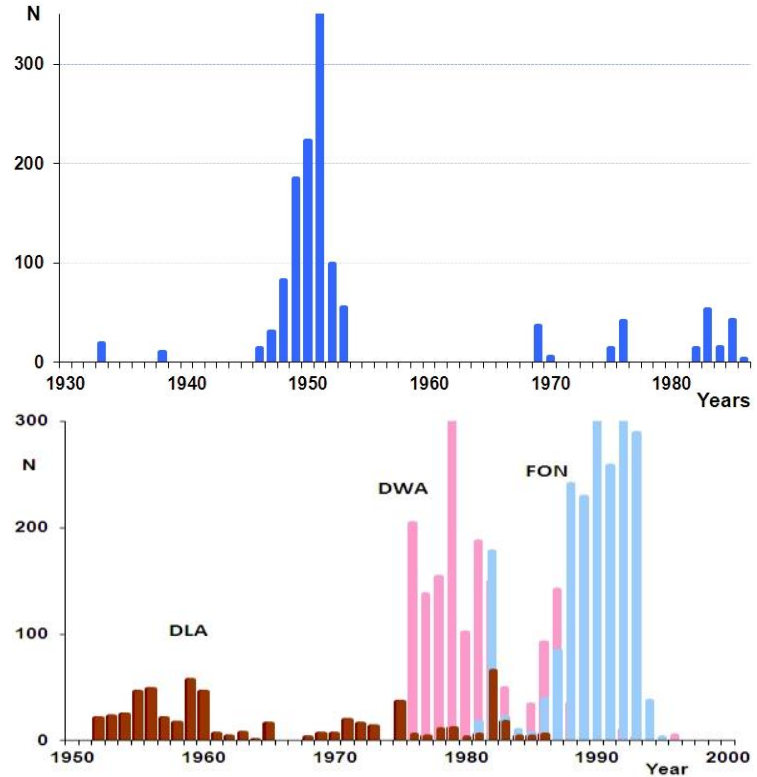

Figure 1: Time distribution of all asteroid positions for AO TSNU (top) and MAO NASU (bottom)

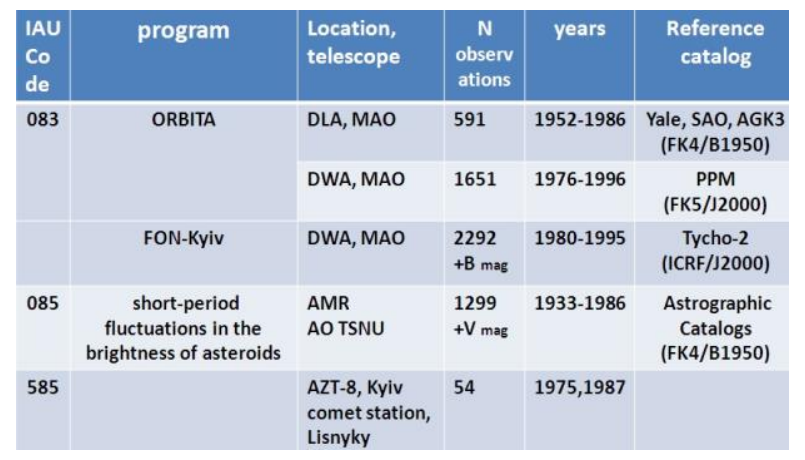

Figure 2: The quantitative data of early Kyiv asteroid observations

The main reason is that for the processing of early observations of asteroids, the methods of measurement and reduction calculations available at that time were used. They did not provide high accuracy in determining the coordinates. Therefore, our earlier observations of asteroids in the AO TSNU, MAO NASU and in other observatories have a larger scatter of $\mathrm{O}-\mathrm{C}$ differences than later observations.

The individual O-C differences for the observations of AO TSNU and O-C histograms for observations of the MAO NASU are presented in Fig. 3 and Fig. 4 respectively. Fig. 3 shows a scatter of O-C values within +-5 arcsec and which presents only one half of all observations, and the other half is ignored. 


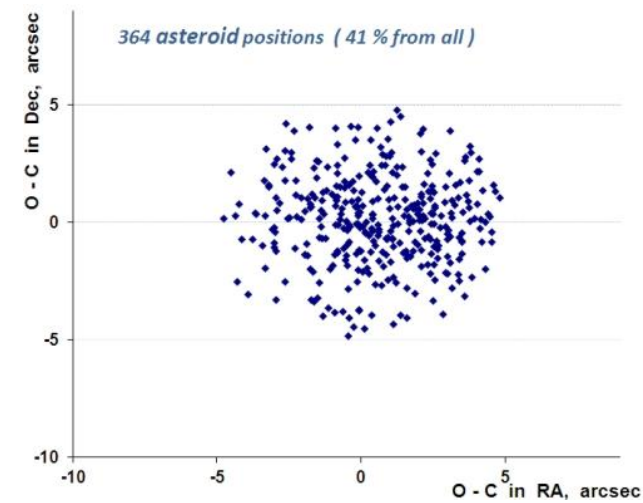

Figure 3: Distribution of O-C differences for AO TSNU asteroid positions

For comparison, Fig. 4 shows the histograms of the distribution of O-C values of asteroids for each of the three series of observations at MAO NASU. The constructed histograms indicate a similar accuracy of coordinates for the first two observational series with DLA and DWA telescopes, the value of which is typical for photographic observations in general. The O-C distribution of asteroids for the third series with FON-Kyiv observations is different from the rest. The values of the root mean square errors for asteroids from these observations are greater, probably due to the involvement of a large number of faint asteroids in the analysis.

The mean values of the $\mathrm{O}-\mathrm{C}$ differences and the standard deviations of $\mathrm{O}-\mathrm{C}$ for three series of asteroid observations at MAO NASU are shown in Fig. 5.
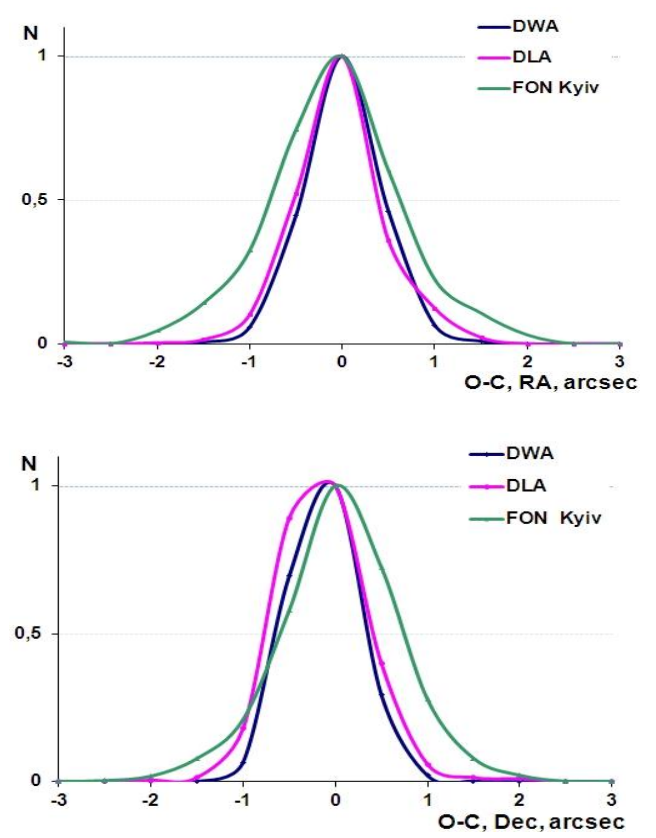

Figure 4: Histograms of the distribution of O-C

\begin{tabular}{l|rcc} 
& DLA & DWA & FON-KYiv \\
MEAN (o-c) RA & -.04 & .01 & -.08 \\
MEAN (o-c) Dec & -.14 & -.12 & .05 \\
RMS (o-c) RA & .47 & .52 & .70 \\
RMS (o-c) Dec & .47 & .46 & .63
\end{tabular}

Figure 5: Mean values of $\mathrm{O}-\mathrm{C}$, standard deviations of $\mathrm{O}-\mathrm{C}$ in arcsec for all positions from three series of asteroid observations at MAO NASU

To process photographic observations of asteroids, various reference catalogs available at that time were used. The reduction of the observations of the AO TSNU was carried out with the Astrographic catalogs. The earliest MAO NASU observations were processed using the Yale, SAO and AGK3 catalogs. The Yale catalog was used to process the very first observations. For the processing of subsequent ones, SAO and AGK3 were used, as a result of which a series of asteroid observations could have various systematic errors (Major et al., 1996). In addition, typical values for the RMS errors for SAO catalog are 1 arcsec in the positions at epoch 1990 , and 1.5 arcsec/century in the proper motions. The corresponding values for the AGK3 catalog in the northern hemisphere are 0.45 arcsec and 0.9 arcsec/century (Roeser et al., 1988).

The second series of MAO NASU observations with the DWA telescope was processed with the PPM catalog, and the FON project observations were processed with the Tycho-2 catalog.

Note that the information on the reference catalogs in the MPC database is fully known only for all recent observations of asteroids, and only for $10 \%$ of early observations (before 1990) (Maigurova et al., 2017).

The combination of asteroid observational data and their use for ephemeris calculations leads to the detection of systematic errors in the positions of asteroids associated with the use of certain reference catalogs.

Previously, Chesley et al. (2010) discussed the detection of systematic biases in star positions of catalogs as deduced from the residuals of asteroid observations. They established that debiased orbits predict omitted observations more accurately than do orbits derived from nondebiased observations. Also, based on the statistical analysis of numerous asteroid observations Vereš et al., (2017) developed a new weighing scheme to be used when performing asteroid orbit determination.

Later, in articles the authors Eggl et al. (2020); Farnocchia et al. (2015), based on a comparison of the coordinates of stars from different catalogs and Gaia, derived a scheme that can be used to correct past astrometric observations of Solar system objects. They provide substantially improved debiasing tables for 26 astrometric catalogs that were extensively used in minor planet astrometry. The first version of the correction table is publicly available at ftp://ssd.jpl.nasa.gov/pub/ssd/debias/debias_2014.tgz.

Note that there are no data in these tables for the Yale, SAO, AGK3 star catalogs, which we used as reference ones in processing the observations. 


\section{New processing of past observations of asteroids}

Based on the above results and the analysis of our data, we carried out a new direct reprocessing of observations using old measurements of plates and new reference catalogs. For the correct transformation of the asteroid coordinates from the system of one catalog to the system of another, our predecessor astronomers published information about the reference stars and Schlesinger's dependences, which were calculated based on measurements of asteroids and reference stars on each plate.

We digitized this published data and used it on 590 plates obtained from observations with DLA in 1952-1986 to determine new coordinates for asteroids in the Tycho-2 and Gaia catalog systems. Unfortunately, for the early (1946-1953) observations of asteroids in the AO TSNU, Schlesinger's dependences for reference stars were not calculated, which does not allow us to re-process the observations with new reference catalogs in a similar way.

Since the observations obtained with DLA telescopes in 1952-1982 at MAO NASU were processed using classical linear reduction algorithms to determine the coordinates of asteroids, our new reprocessing was completely correct.

Cross-identification of the reference stars and coordinates extraction in different catalogs was performed using the services and online catalog data (Ochsenbein et al., 2000) of the Strasbourg Data Center (http://cdsarc.ustrasbg.fr/pub/cats). An updated online version was available for the previous Yale, SAO and AGK3 star catalogs, where all errors found in the process of using these catalogs have been corrected. The first results from this reprocession of asteroid observations are presented in article by Shatokhina et al., 2019. We have now completed the re-processing of all asteroid observations by adding the Gaia EDR3 catalog (Gaia Collaboration, 2021) to the used reference catalogs. All newly determined coordinates in Tycho-2, Gaia DR2 and Gaia EDR3 catalog systems, and previous original coordinates of asteroids are compared with the ephemeris ones from JPL.

The resulting O-C differences in the form of histograms are shown in Fig. 6. For the newly determined coordinates of the asteroids and for the previous original coordinates, the O-C differences are shown side by side for comparison. As a result of re-processing, the standard deviation of $\mathrm{O}-\mathrm{C}$ in both coordinates has decreased. The displacement of the histograms towards the symmetric O-C distribution indicates a decrease in the systematic component of the coordinate error.

The mean values of the O-C differences and the standard deviations of O-C before and after reprocessing with three reference catalogs are shown in Fig. 7.

The standard deviations of the $\mathrm{O}-\mathrm{C}$ differences are schematically illustrated in Fig. 8 separately for each of the most observed minor planets (1) Ceres, (2) Pallas, (3) Yuno, (4) Vesta, (6) Hebe, (7) Iris, (18) Melpomene, (39) Laetitia, (40) Harmonia. When comparing the results before and after reprocessing, a systematic shift is observed on average up to 0.1 arc seconds in both coordinates for each of the nine minor planets. This figure also shows small differences in O-C standard deviations for minor planets (3) Yuno and (40) Harmonia between the new positions in the Tycho-2 and Gaia catalog systems.

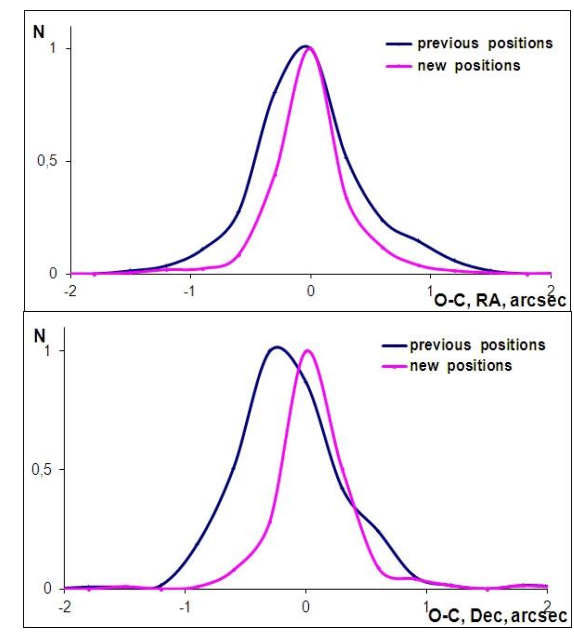

Figure 6: Distribution of O-C differences for previous and new (Gaia EDR3) positions of asteroids

$\begin{array}{lcccc} & \text { original } & \text { Tycho-2 } & \text { Gaia DR2 } & \text { Gaia EDR3 } \\ \text { MEAN (O-c)RA } & -.02 & .01 & .00 & .00 \\ \text { MEAN (O-c) Dec } & -.15 & .06 & .06 & .07 \\ \text { RMS (o-c)RA } & .44 & .33 & .33 & .34 \\ \text { RMS (o-c) Dec } & .42 & .28 & .29 & .29\end{array}$

Figure 7: Mean values of O-C and standard deviations of $\mathrm{O}-\mathrm{C}$ in arcsec for 443 asteroid positions before and after reprocessing with Tycho-2, Gaia DR2 and Gaia EDR3 catalogs.

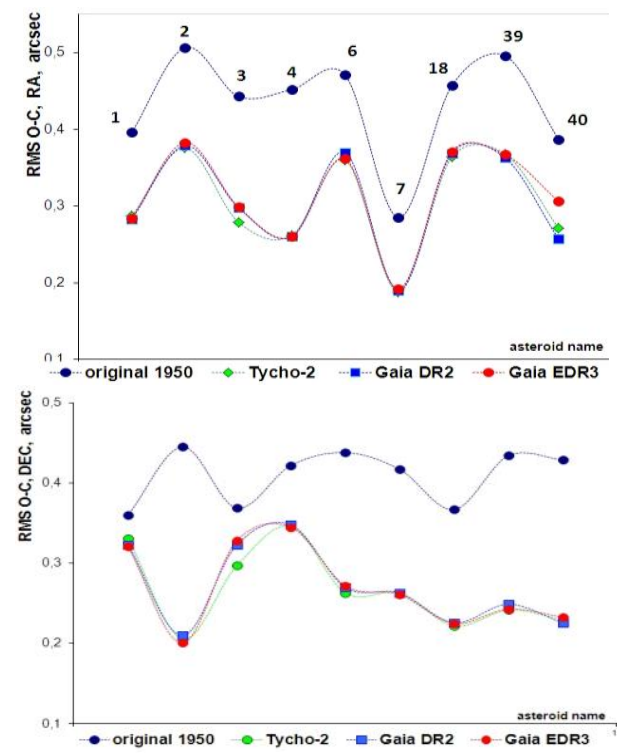

Figure 8: Changes in the RMS values of O-C in RA, Dec coordinates (top, bottom) as a result of using different reference catalogs. (Designations in the figure: 1-Ceres, 2- Pallas, 3- Yuno, 4- Vesta, 6- Hebe, 7- Iris, 18Melpomene, 39- Laetitia, 40- Harmonia)

All asteroid positions determined from the reprocessing of observations with the Tycho-2, Gaia DR2, and Gaia EDR3 catalogs as reference ones are placed on the UkrVO website (http://gua.db.ukr-vo.org/starcatalogs.php). 


\section{Conclusion}

Based on the publications and the MPC database, all data on the positions and magnitudes of asteroids determined from photographic observations at AO TSNU and MAO NASU were collected.

For different series of observations of asteroids, as well as variations in the use of different reference catalogs of stars, various values of the accuracy of the coordinates of asteroids were obtained as a result of the analysis.

Using the Tycho-2, Gaia DR2, and Gaia EDR3 catalogues as a reference, 590 plates exposed with MAO NASU Double Long-Focus Astrograph in 1952-1986 were reprocessed based on previous plate measurements and Schlesinger's dependences using. For asteroid positions in Gaia EDR3 catalog system the mean $\mathrm{O}-\mathrm{C}$ values are 0.00 and 0.07 arc seconds, the RMS O-C values are 0.34 and 0.29 arc seconds in RA, Dec coordinates, respectively. For previous original asteroid positions similar values are -..02; -15 arc seconds and $.44 ; .42$ arc seconds, respectively.

The ephemeris comparison results show a significant improvement in the random and systematic components of the positional accuracy for the new asteroid positions compared to the previous original ones. However, on the whole, the new positions of the asteroids determined in the Tycho-2 and Gaia catalog systems do not differ significantly from each other.

In the processing of the plates, the stars of $6^{\mathrm{m}}-11^{\mathrm{m}}$ magnitudes were used as a reference stars. The absence of coordinates of some bright stars in the second release of the Gaia catalog, as well as the absence of some proper motions of bright stars in the Gaia EDR3 catalog, excluded the possibility of direct reprocessing of some individual asteroid observations. Therefore, about 20 percent of observations were not included in the comparative analysis between the previous and new treatments. Considering that some stars in the Yale, SAO, and AGK3 catalogs have very inaccurate proper motions, the use in the new processing of the averaged values of the stellar coordinate differences instead of the individual ones for stars with coordinates or proper motions temporarily absent in Gaia releases may lead to additional errors.

The data obtained with reprocessed observations of asteroids for this long-term period are highly useful for a more detailed study of the dynamics and modern orbital parameters of asteroids (see, for example, Savanevych et al. 2015; Savanevych et al. 2018; Hromakina et al. 2021; Vavilova et al. 2022) as well as the obtained photometric parameters are very complementary with present-day data for studying changes in brightness and light curves (see, for example, Marzari, 2020).

\section{References}

Andruk V.M., Pakuliak L.K., Golovnia V.V. et al.: 2016, Kinem. Phys. Cel. Bodies, 32, N5, 260.

Blažko S.: 1928, Astronomische Nachrichten, 232, 131, DOI: 10.1002/asna.19282320705.

Chesley S.R., Baer J., Monet D.G.: 2010, Icarus, 210, Is. 1,158 .

Demenko I.M., Lysyakova R.F., Yavorskaya L.N.: 1958, Astronomical circular, 195, 5.

Eggl S., Farnocchia D., Chamberlin A. et al.: 2020, Icarus, 339, id. 113596.

Farnocchia D., Chesley S.R., Chamberlin A.B. et al.: 2015, Icarus, 245, 94.
Gaia Collaboration; Brown A.G.A., Vallenari A., Prusti T. et al: 2021, $A \& A p, 649$, id.A1, 20, DOI: 10.1051/00046361/202039657.

Gavrilov I.V.: 1957, Astronomical circular, 186, 9.

Gavrilov I.V.: 1958, Astronomical Circular, 193, 14.

Gavrilov I.V., Zhdanova, I.G., Onegina, A.B. et al.: 1955, Astronomical circular, 158, 3 .

Golovnia V., Yizhakevych O., Shatokhina S. et al.: 2017, Odessa Astron. Publ., 30, 170.

Golovnya V., Major S.: 2001, On-line Data Catalog: DBGPA 3/05. publ. in: gua.db.ukr-vo.org/starcatalogs.php?whc=asteroids.

Hromakina, T., Belskaya, I., Krugly, Y. et al.: 2021, A\&Ap, 647, A71. doi:10.1051/0004-6361/202039737.

Kaltygina S.V., Major S.P., Moroz G.V. et al.: 1985, VINITI, 8619-B85, 35 p.

Kolchinsky I.G.:1956, Izvestia GAO AN UkrSSR, 1, 2, 37.

Konopl'ova V.P., Dukhnovs'kiy P.G., Polupan P.M. et al.: 1954, Publ. KAO, N6, 91.

Konopl'ova V.P., Dukhnovs'kiy P.G., Sandakova Ye.V. et al.: 1956, Publ. KAO, N7, 105.

Maigurova N.V., Chernetenko Yu.A., Kryuchkovskiy V.F.: 2017, Science and Innovation, 13, N1, 69.

Major S.P., Moroz G.V.: 1984, Astrometria i astrofisika, 51, 69.

Major S.P., Shatokhina S.V.: 1996, Kinematics Phys. Celest. Bodies, 12, N4, 64.

Marzari, F., Rossi, A., Golubov, O., Scheeres, D.J.: 2020, $A J$, 160, 128. doi:10.3847/1538-3881/aba7be.

Onegina A.B.: 1957, Astron. Circ. of the Bureau of Astron. Comm. of the USSR Academy of Sciences, 176, 4.

Onegina A.B.: 1958, Astronomical Circular, 193, 16.

Onegina A.B.: 1960, Izvestia GAO AN UkrSSR, 3, 1, 115.

Onegina A.B.: 1961, Izvestia GAO AN UkrSSR, 4, 1, 73.

Onegina A.B.: 1962, Izvestia GAO AN UkrSSR, 4, 2, 57.

Onegina A.B., Zaslavskaya S.A.: 1964, In book. Astrometry issues, K., Nauk. dumka, 57.

Onegina A.B., Zaslavskaya S.A.: 1970, Byull. Inst. Teor. Astron., 12, 434.

Ochsenbein F., Bauer P., Marcout J.: 2000, Astron. and Astroph. Suppl., 143, 23.

Polupan P.N., Konopleva V.P., Dukhnovskiy P.N. et al.: 1953, Publ. KAO, N5, 169.

Putilin J.: 1929, Astronomische Nachrichten, 237, 87, DOI: 10.1002/asna.19292370506.

Roeser S., Bastian, U.: 1988, Astron. and Astroph. Suppl. Ser., 74, 449.

Sandakova Ye.V., Khinkulova N.A.: 1950, Publ. KAO, N4, 100.

Savanevych, V.E., Briukhovetskyi, O.B., Sokovikova, N.S. et al.: 2015, MNRAS, 451, 3287.

Savanevych, V.E., Khlamov, S.V., Vavilova, I.B. et al.: 2018, A\&Ap, 609, A54.

Shatokhina S.V., Kazantseva L.V., Andruk, V.M.: 2019, Odessa Astron. Publ., 32, 199.

Shatokhina S.V., Kazantseva L.V., Yizhakevych O.M. et al.: 2018, Kinemat. Phys. Cel. Bodies, 34, N5, 270.

Vasilenko N.A., Demenko I.M.: 1979, Byull. Inst. Teor. Astron., 14, N8, 499.

Vavilova, I.B., Yatskiv, Y.S., Pakuliak, L.K. et al.: 2017, IAUS Proceedings, 325, 361, doi:10.1017/S1743921317001661.

Vavilova I.: 2016, Odessa Astron. Publ., 29, 109.

Vavilova I. B., Pakuliak L. K., Protsyuk Y. I., et al.: 2011, Kosm. nauka tehnol., 17, 74.

Vavilova I. B., Pakulyak L. K., Shlyapnikov A. A., et al.: 2012, Kinem. Phys. Cel. Bodies, 28, 2, 85.

Vavilova I.B., Shatokhina S.V., Pakuliak L.K. et al.: 2022, IAUS Proceedings, 364, 6 (accepted).

Vereš P., Farnocchia D., Chesley S.R.: 2017, Icarus, 296, 139.

Vsekhsvyatskiy S.K., Sandakova Ye.V.: 1950, Publ. KAO, N3, 93 . 